Vol. 8 (4): 813-818 (2018)

\title{
STUDY OF RISK FACTORS FOR POSTPARTUM HEMORRHAGE
}

\author{
Ilta Bylykbashi ${ }^{1 *}$, Aferdita Manaj ${ }^{1}$, Mirton Muhametaj ${ }^{1}$ \\ 1 *University Hospital for Obstetric and Gynecology "Queen Geraldine", \\ Tirana, Albania;
}

“Corresponding author author Ilta Bylykbashi, e-mail: ilta.bylykbashi@yahoo.com;

Received September, 2018; Accepted September, 2018; Published October, 2018;

DOI: https://doi.org/10.31407/ijees8424

UOI license: http://u-o-i.org/1.01/ijees/20564080

\begin{abstract}
Postpartum blood loss is difficult to evaluate. Some healthy women tolerate a 500-mL loss of blood, whereas other women become clinically unstable. Postpartum hemorrhage often occurs in women with no identifiable risk factors. Uterine atony is the most common cause of postpartum hemorrhage. In this study, our aim was to identify risk factors for immediate postpartum hemorrhage after vaginal delivery. The source population was all women admitted for labor at gestational week $\geq 23$ at two University Hospital for Obstetric and Gynecology "Queen Geraldine", Tirana, Albania during the period January 1, 2016 to December 31, 2017. After exclusion of women with planned caesarean deliveries, we extracted the study population, which included $114 \mathrm{PPH}$ and a random sample of controls without severe PPH. Active management of labor incorporates three main interventions: administration of a uterotonic medication after delivery of the baby; early cord clamping and cutting; and controlled traction on the umbilical cord while awaiting placental separation and delivery (13). The clinical adoption and practice of active management or its individual components varies throughout the world. Few studies have explored the association between the total duration of active labor and PPH. Several authors have reported that a prolonged second stage of labor is associated with PPH.
\end{abstract}

Key words: Postpartum haemorrhage, risk factor, active management 